\title{
Üstün Yetenekli ve Diğer 4. Sınıf Öğrencilerinin Matematik Problemlerini Çözme Stratejileri Üzerine Bir Araştırma*
}

\section{Aygen KOÇ KOCA**, Ramazan GÜRBÜZ ${ }^{* * *}$}

Öz: $\mathrm{Bu}$ çalışma 4. sınıfta öğrenim görmekte olan üstün yetenekli ve diğer öğrencilerin matematik problemlerini çözme sürecinde kullandıkları stratejilerin incelenmesine yönelik olarak tasarlanmıştır. Araştırma öğrencilerin matematik sorularını çözerken kullandıkları stratejilerin incelenmesine odaklanılan nitel bir çalışmadır. Çalışmaya 3 farklı ilden 55’i üstün yetenekli olan toplam 110 öğrenci katılmıştır. Veri toplama aracı olarak 6 açık uçlu sorudan oluşan bir test kullanılmıştır. Elde edilen veriler içerik analizi tekniği kullanılarak analiz edilmiştir. Analiz sonuçlarına göre üstün yetenekli öğrencilerle diğer öğrencilerin problemlere verdikleri yanıt sayılarının birbirlerine yakın olduğu, geliştirilen strateji sayılarının ve üretilen strateji çeşitliliğinin üstün yetenekli öğrencilerin lehine olduğu tespit edilmiştir. Ayrıca üstün yetenekli öğrencilerin kendilerine sorulan açık uçlu sorulara daha fazla doğru yanıt verdikleri ve aynı sorunun çözümünde birden fazla strateji kullanabilme bakımından da diğerlerinden farklılaştıkları görülmüştür. Her iki gruptaki öğrenciler test etme tahmin etme stratejisini tüm soruların çözümlerinde etkin olarak kullanırken; uç durumları düşünme, tüm olası durumları düşünme ve daha basit benzer problemlerle çözme stratejilerini hiç kullanmamışlardır.

Anahtar Sözcükler: Matematik eğitimi, Problem çözme, Problem çözme stratejileri, Üstün yetenekli öğrenciler, Strateji geliştirme.

\footnotetext{
* Bu çalışmanın verilerinin bir kısmı 12-14 Mayıs 2016 tarihlerinde Fırat Üniversitesi'nde gerçekleştirilen International Conference on MathematicsEducation (ICCME) adlı konferansta sözlü bildiri olarak sunulmuştur. ${ }^{* *}$ Arş. Gör., Adiyaman Üniversitesi, Eğitim Fakültesi, Adıyaman. ORCID ID:0000-0001-9667-7099, akoc@adiyaman.edu.tr

*** Prof. Dr., Adıyaman Üniversitesi, Eğitim Fakültesi, Adıyaman. ORCID ID: 0000-0002-2412-5882, rgurbuz@outlook.com
} 
An Investigation of the Mathematics Problem Solving Strategies Developed by the $4^{\text {th }}$

\title{
Grade Gifted and Other Students*
}

\begin{abstract}
This study aims to examine fourth grade gifted and other primary school students' mathematical problem solving strategies. We have conducted a qualitative study with 55 gifted and 55 other students who are from 3 different cities. A test consisting of 6 open-ended questions was used as a data collection tool and the obtained data were analysed by using the content analysis technique. The results indicate that the numbers of the answers given by gifted and other students were close to each other, and it has been determined that the number of strategies developed by the students and the diversity of strategies they produced were higher in favour of the gifted students. It has also been observed that gifted students gave more correct responses to the open-ended questions comparing to other students. In the same way it was obvious that gifted students used more than one strategy to solve the same questions in most of the cases. In addition, the students in both groups mostly used trial and error strategy. On the other hand, neither group used the strategies called thinking about extreme situations, thinking about all possible situations and solving with simpler similar problems.
\end{abstract}

Key Words: Mathematics Education, Problem solving, Problem solving strategies, Gifted students, Strategy Development.

\section{Giriş}

Günümüzde öğrenenlerin yeteneklerinin ortaya çıkarılabilmesi ve geliştirilebilmesi için alternatif yöntemler ve uygulamalar dikkat çekmeye başlamıştır. Problem çözme yöntemi bu uygulamalar arasında gün geçtikçe önemini arttırmaktadır. Dewey’e göre problem, insan zihnini karıştıran, ona meydan okuyan ve inancı belirsizleştiren her şey olarak tanımlanır (Baykul ve Aşkar, 1987). Problem çözme ise problemle başa çıkmak demektir (Heppner ve Krauskopf, 1987). Bilimsel bir araştırma süreci olarak problem çözme, belli bir amaca ulaşmak için karşılaşılan güçlükleri ortadan kaldırmaya yönelik bir dizi çabayı gerektiren bir süreçtir (Bingham, 1998). Bu süreç, kişinin problemi hissedişinden ona çözüm buluncaya kadar geçirdiği süre şeklinde açıklanmaktadır (Morgan, 1981). Ancak problem çözmenin genellikle bir doğru sonuç bulma olarak algılanması (Altun, 2002), öğrencilerin bir problemle karşılaştıklarında çoğu kez kullanılacak bir kural hatırlamaya çalışmalarına neden olmaktadır. Oysaki problem çözmenin bir kuralı yoktur, ancak bir sistematiği vardır. Öyleki, Lester’e 
(1994) göre problem çözme, basit işlemlerin hatırlanması veya iyi öğrenilmiş prosedürlerin uygulanması değil; yaratıcılığın, eleştirel düşünmenin ve probleme uygun stratejiler geliştirebilmenin birleşiminden oluşan daha karmaşık bir süreçtir. Bu sistematik süreç Polya (1997) tarafından şu dört basamakta özetlenmektedir: (i) Problemin anlaşılması, (ii) Çözümle ilgili stratejinin seçilmesi, (iii) Seçilen stratejinin uygulanması, (iv) Çözümün değerlendirilmesi. Bu nedenle problem çözmek, her ne kadar doğru sonuca ulaşmayı gerektirse de bir süreç olarak değerlendirildiğinde uygun stratejiyi geliştirebilmek de doğru sonuca ulaşmak kadar önemlidir.

Problem çözme matematiksel öğrenmede önemli bir araç ve matematiksel düşünmeyi ön plana çıkaran geniş bir zihinsel süreci ve becerileri kapsayan bir eylem (Altun, 2002) olduğundan, öğrencilerin problem çözme becerilerinin geliştirilmesi aynı zamanda toplumsal gelişmenin sağlanmasında da etkili olacaktır (Güzel, 2004). Schoenfeld'e (1991) göre matematiksel düşünme, dünyaya matematiksel bir bakış açısıyla bakarak modelleme ve sembolleştirme yapabilmek; matematiksel fikirleri, matematiksel araçları kullanarak diğer durumlara uygulayabilmek demektir. Bundan dolayı son yıllarda, iş veya ev gibi gündelik ortamlarda çözülen problemler üzerinde çalışılmasının özgün insan problem çözme sürecini daha iyi temsil edeceği ve bu yüzden gündelik durumlardaki problem çözme ve pratik düşünme üzerine odaklanılması gerektiğine ilişkin görüşler ortaya çıkmaktadır. Problemlerin çözümünde değişik problem çözme stratejileri (sistematik liste yapma, tahmin ve kontrol, diyagram çizme, bağıntı bulma, değişken kullanma, geriye doğru çalışma, tablo yapma vb.) izlenebilir (Altun, 2002; Hatfield, Edward ve Bitter 1997). İzlenen strateji hem problemin yapısına hem de bireyin düşünme şekline göre farklılıklar gösterebilmektedir. Öğrencilerin mevcut bilgi düzeyleri problem çözme sürecinde etkilidir (Gündüz ve Bulut, 2017) ve problem çözme becerilerinin gelişmesi, farklı problemlere uygun stratejiler geliştirmelerine olanak sağlarken matematiksel bilgiyi anlamlandırmalarını da kolaylaştırmaktadır.

Literatürde problem çözme stratejilerine yönelik geliştirilmiş birçok strateji modeli yer almaktadır. Örneğin Millî Eğitim Bakanlığı (MEB) (2009) on altı farklı problem çözme stratejisinden bahsederken Altun (2010) on bir farklı problem çözme stratejisinden bahsetmektedir. $\mathrm{Bu}$ modeller incelendiğinde stratejilerin temelde aynı fakat sayıca farklı değerlendirildikleri görülmektedir. Sayıca farklı olmasının nedenleri arasında her modelin stratejileri farklı ele alması ve bazılarını birleştirerek tek strateji adı altında toplamaları yer almaktadır. Bu nedenle bu çalışmadan elde edilen verilerin açıklanmasında en iyi sonuçları 
veren, Posamentier ve Krulik tarafından 1998 yılında geliştirilen matematiksel problem çözme stratejileri temele alınarak çalışmadan elde edilen veriler incelenmiştir. $\mathrm{Bu}$ araştırmada kullanılan stratejiler aşağıdaki gibidir:

a. Geriye doğru çalışma stratejisi: $\mathrm{Bu}$ strateji, günlük yaşamda da sıkça kullanılan ve problemi çözmek için problemdeki verilerin kullanılarak işlemlere sondan başlanmasını ve geriye doğru işlem yapılmasını içerir.

b. İlişki arama stratejisi: Problemdeki verilerin tüm durumlarının düşünülerek veriler arasındaki bağlantıların veya kuralların ortaya çıkarılarak çözüm yapılmasıdır.

c. Farklı bakış açısı ile düşünme stratejisi: $\mathrm{Bu}$ da yine günlük hayatta sıkça kullanılan stratejiler arasındadır. Bu strateji, problemin yönlendirdiği durumdan ziyade çok farklı bir durumdan yola çıkılarak probleme çözüm geliştirilmesidir.

d. Daha basit benzer problemlerle düşünme stratejisi: Verilen problemin aynı özellikteki daha basit bir problem yardımıyla çözülmesidir.

e. Verileri organize etme stratejisi: Problemdeki verilerin amaca uygun gruplandirılıp düzenlenerek, sistemli bir şekilde problemin çözülmesidir.

f. Test etme tahmin etme stratejisi: Problem çözümü için geliştirilen bir dizi sistematik, bilinçli ve geçerli tahminlerin test edilerek problemin çözülmesidir.

g. Çizim yapma stratejisi: Problemdeki veriler arasındaki ilişkilerin ve bağlantıların görünür hâle gelmesi için görsel temsillerin kullanılarak çözüme ulaşılmasıdır.

h. Uç durumları düşünme stratejisi: Birden fazla değişkenin yer aldığı problemlerde, değişkenlerden birinin sabit tutulup diğeri ya da diğerlerinin uç durumlarının dikkate alınarak problemlerin çözülmesidir.

i. Tüm olası durumları düşünme stratejisi: Problem çözümünde veriler kullanılarak oluşabilecek tüm olası durumların değerlendirilmesidir.

j. Mantıksal akıl yürütme stratejisi: Problem çözümünde yapılan bir çıkarım, ikinci bir çıkarımın yapılmasına imkân tanır ve problem çözülene kadar bu şekilde devam edilir.

Problem çözme, öneminden dolayı dünyanın her yerindeki öğretim programlarında ayrıntılı olarak ele alınmıştır. Örneğin, Amerika Birleşik Devletleri’nde matematik eğitiminde söz sahibi olan en önemli iki kuruluş National Council of Teachers of Mathematics (NCTM) (1989; 2000) ve Council of Chief State School Officers (CCSSO) (2010) problem çözmenin matematik eğitimindeki rolü ile ilgili benzer ifadeler benimsemiştir. Öğrencilerin problem çözmeyi matematiksel içeriği anlamak ve keşfetmek, matematiğin içindeki ve dışındaki 
durumlarda problemleri formüle etmek, orijinal problem durumlarının doğruluğunu kanıtlamak ve yorumlamak, problemleri çözmede çeşitli stratejiler geliştirmek ve uygulamak ve matematiği anlamlı olarak kullanmada güven duymak için kullanabileceklerini vurgulamışlardır. Ülkemizdeki matematik eğitim programları bu doğrultuda incelendiğinde problem çözme, kazandırılması öngörülen temel beceriler arasında yer almakta ve problem çözme becerilerinin geliştirilmesine yönelik uygulamalar özellikle vurgulanmaktadır (MEB, 2015). Eğitim programlarının güncellenmesi ile ilgili yapılan son çalışmalarda, öğrencilerin matematiksel problem çözme gücünü ve problemlerin çözümüne uygun stratejileri geliştirmek için muhakeme becerilerini geliştirmeye önem verilmekte ve bu becerilerin günlük yaşam durumlarına aktarılabilmesine dikkat edilmektedir (Verschaffel, De Corte, Lasure, Van Vaerenbergh, Bogaerts ve Ratinckx, 1999; CCSSO, 2010; NCTM, 2000; MEB, 2015).

Bu kapsamda gerçek dünya koşullarındaki problemlerin çözümlenmesinde bireylerin çözüm arama, araştırma, bilgi edinme arzusu gibi eğilimlerinin de bir değişken olabileceği ve bu çerçevede düşünme ihtiyacı gibi bir kavramın işlevsel olabileceği düşünülebilir (Coutinho, Weimer-Hastings, Skowronski ve Britt, 2005). Benzer olarak Woo, Harms ve Kuncel (2007) düşünme ihtiyacının zekâ ve bilgili olmak ile yakından ilişkili bir kişilik değişkeni olduğunu belirtmektedir ve bunun güncel yaşam için önemine vurgu yapmaktadır. Düşünme ihtiyacının, gerçek dünya koşullarındaki problemlerin çözümlenmesindeki işlevselliği ve zekâ ile olan ilişkisi göz önünde bulundurulduğunda üstün yetenekli bireylerin problem çözme stratejileri bir merak unsuru oluşturmaktadır. Üstün yeteneklilik Renzulli ve Reis’e (1985) göre, ortalamanın üzerinde bir kabiliyet, yaratıcı düşünme ve görev sorumluluğunun toplamıdır. Özellikle matematikte üstün yetenekli bireyler, matematiksel fikirleri ve matematiksel mantığı anlamada üst düzey kabiliyet göstermektedir (Miller, 1990). Rus psikolog Krutetskii’ye göre matematiksel düşünüş şekli; dünyayı, matematiksel olmayan bir sürü olayı, olguyu matematiksel prizmadan bakarak görme eğilimidir (Krutetskii, 1976). Dolayısıyla matematikte üstün yetenekliler için problemler vasıtasıyla üstün performans göstermeleri ve akranlarının aksine problem çözümlerinde farklı stratejiler kullanmaları beklenen durumlardır. Matematikte üstün yeteneklilerin dikkat çeken bu üst düzey zihinsel becerileri matematik problemlerinde akranlarıyla kıyaslanınca ne derece belirginleşmektedir? Bu durum, bu çalışmanın gerekçesini oluşturmaktadır. $\mathrm{Bu}$ çalışmada literatürde belirgin şekilde kendisini gösteren üstün yeteneklilerin akranlarına göre üst düzey problem çözme ve strateji geliştirme becerileri irdelenerek üstün yeteneklilerin akranlarıyla performans karşılaştırması yapılacaktır. 
Özbay (2013) çalışmasında üstün yetenekli öğrencilerin problemleri öğretmenin betimlediği biçimde değil de kendi usullerine göre çözdüklerini belirtmektedir. MEB’in 2009’daki Mesleki Eğitim ve Öğretim Sisteminin Güçlendirilmesi Projesi kapsamındaki yayınında, matematik alanındaki özel yetenekli öğrencilerin yaşıtlarına göre zor problemleri çözebildiği ifade edilmektedir. Akranlarından daha hızlı ve sistematik olarak problemleri çözebildikleri ve diğer öğrencilerle kıyaslayınca daha fazla sayıda strateji geliştirebildikleri yapılan çalışmalarla ortaya çıkarılmıştır (Garderen ve Montague, 2003). Bu bağlamda, bu araştırmada 4. sınıfta öğrenim gören üstün yetenekliliği tanılanmış ve bu yönde eğitim alan öğrenciler ile diğer öğrencilerin matematik problemlerinin çözümünde kullandıkları problem çözme stratejilerinin karşılaştırılarak incelenmesi amaçlanmıştır.

\subsection{Problem Durumu}

Bu çalışmanın amacı ilkokul 4. sınıfta öğrenim gören üstün yetenekliliği tanılanmış ve bu yönde eğitim alan öğrenciler ile diğer öğrencilerin matematik problemlerinin çözümünde kullandıkları stratejileri karşılaştırmalı olarak incelemektir. Bu amaç doğrultusunda aşağıdaki sorulara cevap aranmıştır:

- İlköğretim 4. sınıfta öğrenim gören üstün yetenekli öğrenciler ve diğer öğrenciler, matematik dersinde hangi problem çözme stratejilerini kullanabilmektedir?

- Üstün yetenekli öğrenciler ile diğer öğrencilerin matematik problemlerini çözme stratejileri arasında ne gibi farklılıklar görülmektedir?

\section{Yöntem}

\section{Araştırmanın Modeli}

$\mathrm{Bu}$ araştırma 4. sınıfta öğrenim görmekte olan üstün yetenekli öğrencilerle diğer öğrencilerin matematik sorularını çözerken kullandıkları stratejilerin incelenmesine yönelik durumların niteliği üzerine odaklanıldığı betimsel bir çalışma olup çalışmada nitel araştırma tekniği kullanılmıştır. Yıldırım ve Şimşek’e (2005) göre nitel çalışmalar, algıların ve olayların doğal ortamda gerçekçi ve bütüncül bir biçimde ortaya konmasına yönelik bir sürecin izlendiği araştırma türüdür. Bu bağlamda, çalışmada olaylar arası ilişkileri ortaya çıkarmak ve elde edilen durumu etraflıca tanımlayarak açıklayabilmek için nitel araştırma tekniklerinden durum çalışması temele alınarak inceleme yapılmıştır. Hancock ve Algozzine (2016) durum çalışmasını, kendi doğal şartları altında meydana gelen olayların zaman ve mekân kısıtlaması 
altında çeşitli veri toplama araçları kullanarak zengin bir şekilde betimleyen çalışmalar olarak tanımlamaktadır.

\section{Çalışma grubu}

Bu araştırma 2015-2016 eğitim öğretim yılı II. yarıyılında üç farklı ildeki üç farklı okulda eğitim görmekte olan 55 üstün yetenekli ve 55 diğer öğrenci (Burada diğer öğrenci ifadesi özellikle tercih edilmiştir. Diğer ifadesindeki kasıt, üstün yetenekli olabileceği hâlde tanılamaya alınmamış öğrencilerinde yer aldığı grubu ifade etmektedir.) ile gerçekleştirilmiştir. Birinci ilden 9' u üstün yetenekli olan 21 öğrenci, ikinci ilden 31' i üstün yetenekli olan 61 öğrenci ve üçüncü ilden 15' i üstün yetenekli olan 28 öğrenci çalışmaya katılmıştır. Çalışma grubunda yer alan üstün yetenekli öğrencilerin tanılanması Rehberlik ve Araştırma Merkezleri (RAM) tarafından yapılmıştır. Araştırmaya katılan öğrencilerin kimliklerini gizli tutmak amacıyla üstün yetenekliler öğrenciler Ü1, Ü2...şeklinde; diğer öğrenciler ise D1, D2...şeklinde kodlanmıştır.

\section{Verilerin Elde Edilmesi ve Analizi}

Araştırmada, öncelikle konuyla ilgili literatür taraması yapılmış ve araştırmanın amacı doğrultusunda araştırmacılar tarafından "Problem Çözme Testi" taslak formu hazırlanmıştır. Taslak formun maddeleri belirlenirken, literatürde yer alan ve bilimsel araştırmalarda kullanılan ilkokul 4. sınıf düzeyine uygun sorular araştırılmış ve soruların bir kısmı katılımcıların maksimum düzeyde farklı stratejiler geliştirebilmeleri için araştırmacılar tarafından yeniden düzenlenmiştir. Sekiz maddeden oluşan taslak; iki alan eğitimcisi, bir ölçme değerlendirme uzmanı ve bir dil uzmanının görüşlerine sunulmuştur. Uzmanlardan alınan görüş ve öneriler doğrultusunda hazırlanan formda gerekli değişiklikler yapılmıştır. Örneğin birinci ve dördüncü soruların öğrenciler tarafından anlaşılmasını kolaylaştırmak amacıyla, soruların ifadelerinde daha açıklayıcı değişiklikler yapılmıştır. Bu değiş̧iklikler sonucunda soruların hem üstün yeteneklilere hem de diğerlerine uygun olması sağlanarak "Problem ÇözmeTesti”nin nihai formatı oluşturulmuştur. Çalışmada kullanılan 8 maddeden ikisi, öğrencilerin sorunun çözümü için strateji geliştirmemiş olmaları nedeniyle analize dâhil edilmemiştir. Öğrencilerin bu sorular için strateji geliştirememiş olmaları soruların yapısından kaynaklanmış olabilir. 
Tablo 1: Çalışmada Kullanılan Problemlerin Çözümünde Kullanılacağı Düşünülen Stratejilerin Dağılımı

\section{Problemler}

1- Aşağıdaki kovalardan $12 l$ olanı su ile doludur. Bu kovadaki suyu diğer kovalara aktararak en az kaç hamlede iki adet 6l su elde edebiliriz?
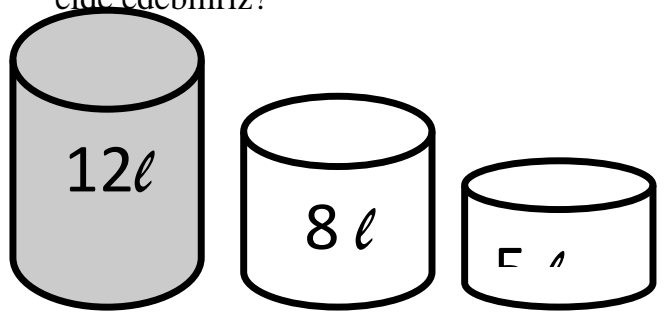

2- Așağıdaki şekilde 3,5,7,11,13,17,19,23 sayıları nasıl yerleştirilirse, taralı bölge hariç her satır ve sütundaki sayıların toplamları birbirine esit olur?

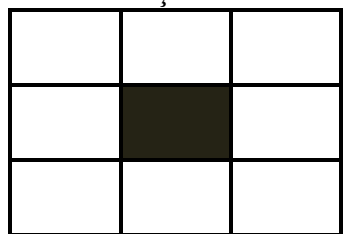

3- Bir kızın erkek kardeşlerinin ve kız kardeşlerinin sayısı birbirine eşittir. Fakat her erkeğin kız kardeşlerinin sayısı, diğer erkek kardeşlerinin sayısının 2 katıdır. Bu ailede kaç kız, kaç erkek kardeş vardır?

4. Bir çemberin üstünde sıralanan çocuklardan 5.si ile 19.su tam karşı karşıya denk gelmiştir. Bu çemberde toplam kaç çocuk sıralanmıştır?

5. Hiçbir rakamı sıfır olmayan öyle iki doğal sayı bulunuz ki, çarpımları 1 milyon olsun?

6. Aşağıdaki şekildeki boşluklara +,-,x,/ (toplama, çıkarma, çarpma,bölme) sembollerini birer defa kullanarak ok yönünde öyle yerleştiriniz ki, kutucuklardaki işlemlerden çıkan sonuç 17 olsun? (Her sembol bir defa kullanılacak)

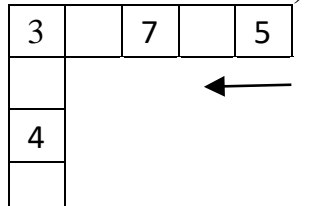

\section{Kullanılması Beklenen Stratejiler}

1. Geriye doğru çalışma

2. Test etme tahmin etme

3. Çizim yapma

4. Farklı bakış açısı ile düşünme

5. Mantıksal akıl yürütme
1. İlişki arama
2. Test etme tahmin etme
3. Mantıksal akıl yürütme

1. İlişki arama

2. Test etme tahmin etme

3. Çizim yapma

4. Mantıksal akıl yürütme

1. İlişki arama

2. Farklı bakış açısı ile düșünme

3. Verileri organize etme

4. Tahmin etme test etme

5. Çizim yapma

6. Mantıksal akıl yürütme

1. Daha basit benzer problemlerle düşünme

2. Mantıksal akıl yürütme

3. Test etme tahmin etme

4. Geriye doğru çalışma

5. İlişki arama

1. İlişki arama

2. Verileri organize etme

3. Test etme tahmin etme

4. Tüm olası durumları düşünme

5. Mantıksal akıl yürütme 
Uygulama yapılan okullar, izin alınan ve çalışmaya katılmak isteyen okullar arasından amaçlı örneklem yöntemlerinden maksimum çeşitlilik örneklemesi yöntemine göre belirlenmiştir. Pek çok durumda olgu ve olayların keşfedilmesinde ve araştırılmasında yararlı olan amaçlı örnekleme, zengin bilgiye sahip olduğu düşünülen durumların derinlemesine çalışılmasına olanak verir (Patton, 1987). Uygulamalar gerekli izinler alındıktan ve uygulama saatleri belirlendikten sonra bir ders saati süresinde (40 dk) iki ilde araştırmacılar tarafından, üçüncü ilde ise BİLSEM'de görev yapan bir matematik öğretmeni tarafından yapılmıştır. Uygulamalar esnasında öğrencilerin sadece problemlerin anlamlarına yönelik soruları cevaplandırılmış, bu soruların dışındaki sorularına öğrencileri yönlendirmemek için cevap verilmemiştir. Örneğin testte yer alan birinci soruda belirtilen “Elimizde 12L, 8 L ve 5 L lik üç adet kova var. Bu kovalardan sadece 12 litrelik kova su ile dolu. Bu suyu diğer kovalara aktararak en az hamlede iki tane 6 L'lik su elde ediniz. "ifadesinde öğrenciler 8 ve 5 litrelik kovaların her bir kullanımda tamamen mi doldurulacağını yoksa istedikleri kadar su koyabilme haklarının olup olmadığını sormuşlar, bu soru araştırmacılar tarafından her bir kullanımda kovaların tamamen doldurulması gerektiği yönünde cevaplandırılmıştır.

Çalışma verileri, öğrencilerden yazılı olarak elde edilen cevap kâğıtlarındaki çözümlerden oluşmaktadır. Analizler yapılırken öğrencilerin cevap kâğıtlarındaki yanıtları dikkatlice incelenmiş, her bir sorunun çözümü için öğrencilerin sergiledikleri yaklaşım ve düşünceler not alınmış ve soruda kullanılan stratejiler için saptamalarda bulunulmuştur. Bu süreç birbirinden bağımsız deneyimli iki araştırmacı tarafından birden fazla defa tekrarlanarak verilerin kodlamaları gerçekleştirilmiş ve kodlayıcılar arası güvenirlik katsayısı Huberman ve Miles'ın (1994) güvenirlik formülü ile hesaplanarak \%93 bulunmuştur. Analizin son aşamasında anlamsal açıdan benzer olan kodlar dikkate alınarak soruların çözümleri için geliştirilen stratejiler belirlenmiştir. Bu doğrultuda verilerin analizinde içerik analizi tekniği kullanılmıştır. İçerik analizi, belirli kurallara dayalı kodlamalarla bir metnin bazı sözcüklerinin daha küçük içerik kategorileri ile özetlendiği sistematik, yinelenebilir bir tekniktir (Akgün, Büyüköztürk, Çakmak, Demirel ve Karadeniz 2010). Hazırlanan kategoriler literatürde yer alan problem çözme stratejileri ile karşılaştırılarak elde edilen verilerin açıklanmasında en iyi sonuçları verdiği düşünülen Posamentier ve Krulik' in (1998) çalışmalarında kullandıkları problem çözme stratejileri dikkate alınmış, veriler detaylı olarak incelenmiştir. Problem çözme stratejilerine 
yönelik geliştirilen diğer modellerde Posamentier ve Krulik'in çalışmalarında belirttiklerinden farklı olarak Model inceleme, Eleme, Bilinenleri eleştirel biçimde inceleme, Canlandırma gibi birçok farklı strateji yer almaktadır (Charles ve Lester, 1982; Kennedy ve Tipps 1991). Bu çalışmanın veri analizlerinde bu stratejilerin öğrenciler tarafından kullanılmadığı tespit edilmiştir. Bu nedenle çalışmada öğrencilerin problem çözümlerinde geliştirdikleri stratejileri Posamentier ve Krulik’in çalışmalarında belirttikleri problem çözme stratejileri daha iyi ifade etmektedir. Ayrıca hem üstün yetenekli öğrencilerin hem de diğerlerinin Posamentier ve Krulik tarafından geliştirilen stratejilerden uç durumları düşünme, tüm olası durumları düşünme ve daha basit benzer problemlerle çözme stratejilerini hiç kullanmamaları nedeniyle bu stratejilere analizde yer verilmemiştir. Yin’e (1994) göre nitel çalışmalardan elde edilen veriler, bireylerin düşüncelerini doğrudan yansıtmaktadır. Bu nedenle çalışmada bazı alt kategoriler için örnek olabilecek, öğrencilerden alınan yanıtların bir kısmı aynen aktarılmıştır.

\section{Bulgular}

$\mathrm{Bu}$ bölümde üstün yetenekli olan ilkokul 4. sınıf öğrencilerinin ve diğer 4. sınıf öğrencilerinin Problem Çözme Testi’ne verdikleri yanıtlarda kullandıkları problem çözme stratejilerinin analiz sonuçları verilmiştir. Öğrenci kâğıtlarından alınan cevaplar her bir soru için tablolar kullanılarak detaylıca incelenmiştir.

Analiz sonuçlarına göre çalışmaya katılan üstün yetenekli öğrencilerle diğerlerinin sorulara verdikleri yanıt sayıları ile doğru yanıt sayıları, sorulara geliştirdikleri toplam strateji sayıları ile her bir soru için üretilen stratejilerin çeşitliği Tablo 2' de görülmektedir. Yapılan çalışma sonucunda üstün yetenekli ve diğer öğrencilerin hem genel olarak sorulara birbirlerine yakın sayıda yanıt verdikleri hem de kullandıkları strateji sayısı bakımından birbirlerine benzer sayıda çözüm ürettikleri tespit edilmiştir. Öğrenciler tarafindan kullanılan stratejiler Tablo 2' de Geriye doğru çalışma (1), İlişki arama (2), Farklı bakış açısı ile düşünme (3), Verileri organize etme (4), Test etme ve tahmin etme (5), Çizim yapma (6) ve Mantıksal akıl yürütme (7) şeklinde numaralandırılarak kullanılmıştır.

Tablo 2: Katılımcıların sorulara verdikleri yanıt ve strateji sayıları ile üretilen stratejiler ve farklılıkları

\begin{tabular}{|c|c|c|c|c|c|c|c|c|}
\hline \multirow[b]{2}{*}{ SORU } & \multicolumn{4}{|c|}{ ÜSTÜN YETENEKLİ ÖĞRENCİLER } & \multicolumn{4}{|c|}{ DİĞER ÖĞRENCİLER } \\
\hline & $\begin{array}{l}\text { YANIT } \\
\text { SAYISI }\end{array}$ & $\begin{array}{l}\text { DOĞRU } \\
\text { SAYISI }\end{array}$ & $\begin{array}{l}\text { STRATEJI } \\
\text { KULLANIM } \\
\text { SAYISI }\end{array}$ & $\begin{array}{l}\text { KULLANILAN } \\
\text { STRATEJILER }\end{array}$ & $\begin{array}{l}\text { YANIT } \\
\text { SAYISI }\end{array}$ & $\begin{array}{l}\text { DOĞRU } \\
\text { SAYISI }\end{array}$ & $\begin{array}{l}\text { STRATEJI } \\
\text { KULLANIM } \\
\text { SAYISI }\end{array}$ & $\begin{array}{l}\text { KULLANILAN } \\
\text { STRATEJILER }\end{array}$ \\
\hline 1 & 40 & 2 & 55 & $1,5,6,7$ & 41 & 0 & 46 & $5,6,7$ \\
\hline 2 & 33 & 8 & 39 & $2,5,7$ & 41 & 14 & 47 & $2,5,7$ \\
\hline
\end{tabular}




\begin{tabular}{lccclclll}
\hline 3 & $\mathbf{2 5}$ & 11 & $\mathbf{3 4}$ & $2,5,6,7$ & $\mathbf{2 7}$ & 0 & $\mathbf{3 2}$ & $2,5,6$ \\
\hline 4 & $\mathbf{4 8}$ & 19 & $\mathbf{7 0}$ & $2,3,4,5,6$ & $\mathbf{3 8}$ & 9 & $\mathbf{5 2}$ & $2,3,4,5,6$ \\
\hline 5 & $\mathbf{1 8}$ & 5 & $\mathbf{2 1}$ & $1,2,5$ & $\mathbf{1 2}$ & 5 & $\mathbf{1 2}$ & $1,2,5$ \\
\hline 6 & $\mathbf{3 4}$ & 23 & $\mathbf{3 6}$ & 2,5 & $\mathbf{2 7}$ & 4 & $\mathbf{3 0}$ & $2,3,5$ \\
\hline Toplam & $\mathbf{1 9 8}$ & 68 & $\mathbf{2 5 5}$ & $1,2,3,4,5,6$ & $\mathbf{1 1 8}$ & 32 & $\mathbf{2 1 9}$ & $1,2,3,4,5,6$ \\
\hline
\end{tabular}

Tablo 2 genel olarak incelendiğinde, her ne kadar öğrencilerin soruları doğru çözme oranları düşük olsa da sorulara üretilen çözüm stratejilerinin fazla sayıda olduğu ve çeşitlilik gösterdiği görülmektedir. Bazı öğrencilerin hatalı çözüm yaptığı halde strateji üretmesi ve ayrıca kimi öğrencilerin de soruların çözümünde birden fazla strateji kullanmaları bu çeşitliliğin nedenleri arasında sayılabilir. Elde edilen sonuçlara göre hem üstün yetenekli hem de diğer öğrencilerin bir kısmı, aynı sorunun çözümünde birden fazla strateji kullanmıştır (Tablo 3). Problem çözme testinde yer alan sorular her ne kadar birden fazla strateji kullanımına uygun olsa da, sorular tek bir strateji kullanılarak da cevaplandırılabilecek niteliktedir. Aynı sorunun çözümünde birden fazla stratejinin kullanılması genellikle bir strateji kullanımının öğrenciyi sonuca ulaştırmaması sonucunda gerçekleşmiştir. saylları

Tablo 3: Öğrencilerin soru çözümlerinde birden fazla kullandıkları stratejiler ve doğru-yanlış

\begin{tabular}{|c|c|c|c|c|c|c|}
\hline \multirow[t]{2}{*}{ SORU } & \multicolumn{3}{|c|}{ ÜSTÜN YETENEKLİ ÖĞRENCİLER } & \multicolumn{3}{|c|}{ DİĞER ÖĞRENCİLER } \\
\hline & $\begin{array}{l}\text { KULLANILAN } \\
\text { STRATEJILER }\end{array}$ & $\begin{array}{l}\text { DOĞRU } \\
\text { SAYISI }\end{array}$ & $\begin{array}{l}\text { YANLIŞ } \\
\text { SAYISI }\end{array}$ & $\begin{array}{l}\text { KULLANILAN } \\
\text { STRATEJILER }\end{array}$ & $\begin{array}{l}\text { DOĞRU } \\
\text { SAYISI }\end{array}$ & $\begin{array}{l}\text { YANLIŞ } \\
\text { SAYISI }\end{array}$ \\
\hline 1 & $1,5,6,7$ & 2 & 13 & 5,6 & & 5 \\
\hline 2 & $2,5,7$ & 1 & 5 & 2,5 & 2 & 4 \\
\hline 3 & $2,5,6,7$ & 5 & 4 & $2,5,6$ & & 5 \\
\hline 4 & $2,3,4,6$ & 12 & 10 & $2,4,5,6$ & 7 & 7 \\
\hline 5 & $1,2,5$ & 2 & 1 & & & \\
\hline 6 & 2,5 & & 2 & 2,5 & & 3 \\
\hline
\end{tabular}

Tablo 3’te öğrencilerin birden fazla strateji kullanarak yaptıkları doğru-yanlış çözüm sayıları ile kullanılan stratejiler yer almaktadır. Örneğin birinci soruda üstün yetenekli öğrencilerden 15’i; diğerlerinden ise 5’i birden fazla strateji kullanarak soruyu yanıtlamıştır. Tablo 2 ve 3 incelendiğinde tek bir sorunun çözümünde üstün yetenekli öğrencilerin diğerlerine göre farklı stratejiler kullanmayı daha fazla tercih ettikleri görülmektedir. Bu durum en fazla birinci, ikinci, üçüncü ve beşinci sorularda ortaya çıkmıştır. Kullanılan stratejiler bakımından ortaya çıkan bir başka sonuç ise her iki gruptaki öğrencilerin test etme tahmin etme stratejisini tüm sorularda kullanmış olmalarıdır. Ayrıca, üstün yetenekli öğrencilerin geriye doğru çalışma stratejisini diğerlerine göre daha fazla kullanmayı tercih ettikleri görülmektedir. Öğrenciler 
ikinci, dördüncü ve beşinci soruların çözümlerinde aynı stratejileri kullanmıştır ve en fazla dördüncü soruda strateji kullanmıştır.

Aşağıdaki Tablolar (Tablo 4,5,6,7,8,9) çalışmada kullanılan her bir soruya ait, öğrencilerden alınan yanıtlara göre elde edilen verilerin örnek öğrenci yanıtlarıyla açıklanarak özetlendiği ve her bir soru maddesinde öğrencilerin kullandıkları stratejilerin belirtildiği açıklamaları içermektedir.

Tablo 4: Birinci sorunun analizleri ve örnek öğrenci yanıtları

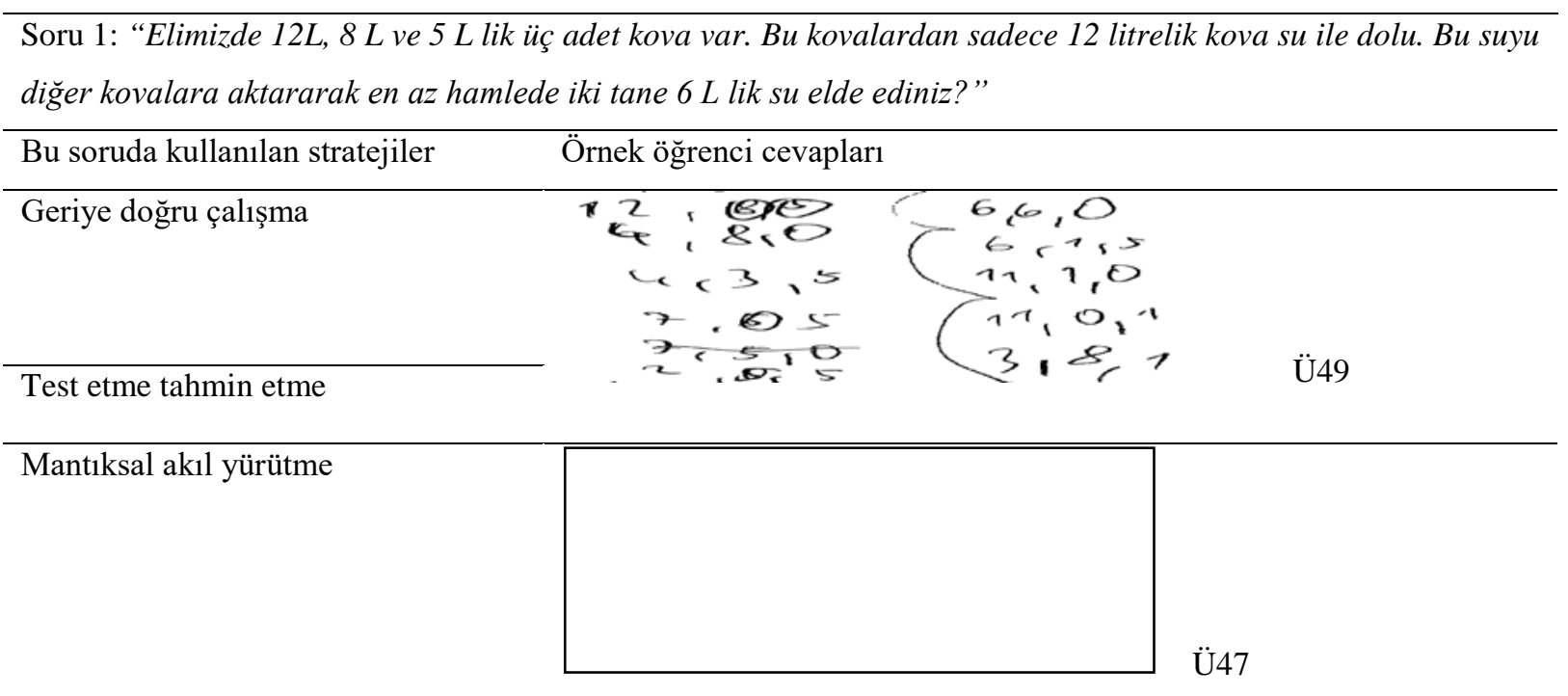

Çizim yapma

Birinci soruda öğrenciler dört farklı strateji kullanarak, strateji içeren 101 çözüm geliştirmiştir. Bu soruya 40’1 üstün yetenekli olan toplam 81 öğrenci yanıt vermiştir. Her ne kadar üstün yetenekli öğrenciler ile diğer öğrencilerin strateji çeşitliliği benzer olsa da üstün yetenekli öğrenciler bu sorunun çözümünde diğerlerine göre geriye doğru çalışma stratejisini fazladan (3 adet) kullanmıştır (Tablo 2). Bu stratejiyi kullanan Ü49 kodlu öğrenci, öncelikle çalışma kâğıdının ilk sütununda test etme tahmin etme stratejisini kullanarak işlem yapmaya başlamış ancak kullandığı strateji çözüm için sonuç vermeyince geriye doğru çalışma stratejisini kullanarak sorunun çözümünde elde edilmesi gereken son basamaklardan faydalanarak soruyu çözmüştür. Ü47 kodlu öğrencinin sorunun çözümü için mantıksal akıl yürütme stratejisini kullanarak soruda verilen değerleri tablo yaparak özetlediği ve çözümünü 
sistemli hâle getirmeyi tercih ettiği görülmektedir. Çizim yapma stratejisini kullanan Ü33 kodlu öğrenci sorudaki verileri şekillere dökerek birkaç basamakta incelemiştir. Öğrencinin ilk satırda kullandığı şekilde soruyu çözerken net ifadeler kullandığı ancak daha sonraki basamaklarını net ifade etmediği görülmektedir.

Birinci soruda hem birden fazla strateji kullanmaları hem de diğerlerine göre farklı bir strateji kullanmaları bakımından üstün yetenekli öğrencilerin diğerlerinden farklılaştığı görülmektedir (Tablo 2 ve 3). Öğrencilerin bu soruyu çözerken fazla strateji kullanmalarının nedeni, sorunun doğasından ve daha önce benzer bir problemle karşılaşmamış olmalarından kaynaklanıyor olabilir. Bu soruyu çözen öğrenciler sorunun çözümünde veriler arasında bağ kurmaya çalışmış ve tablolardan yararlanarak hamle sayılarını belirlemiştir. Her ne kadar verilen doğru yanıt sayısı fazla olmasa da öğrencilerin bu soruda çok sayıda strateji kullandıkları ortaya çıkmıştır. Ayrıca, bu sorunun çözümünde üstün yetenekli öğrencilerin bir kısmı diğerlerine göre aynı sorunun çözümü için daha fazla birden fazla strateji kullanmıştır (Tablo 3). Öğrencilerin kullandıkları strateji çeşitliliği ise üstün yeteneklilerin lehinedir.

Tablo 5: İkinci sorunun analizleri ve örnek öğrenci yanıtları

Soru 2: Şekildeki karelere 3,5,7,11,13,17,19,23 sayılarını nasıl yerleştirirsek, her satır ve sütundaki sayıların toplamları birbirine eşit olur?

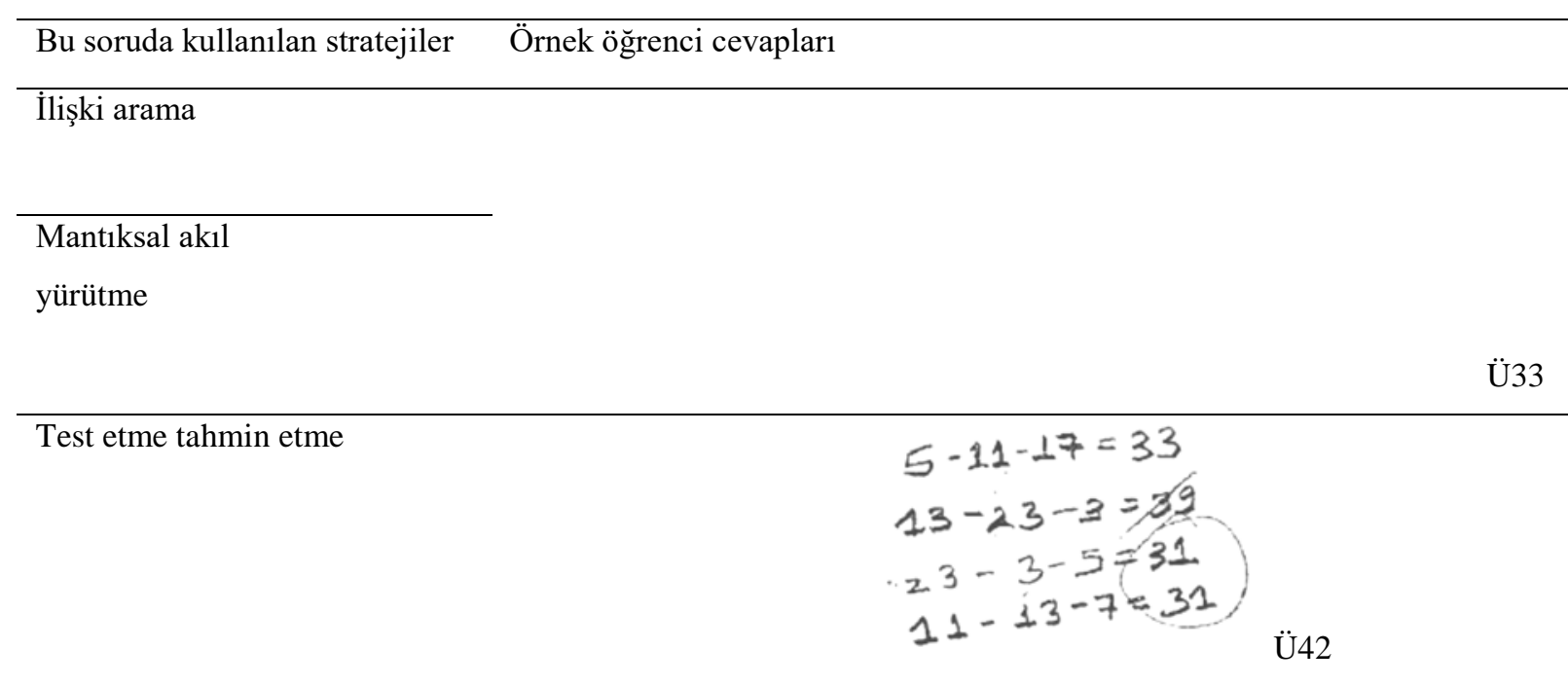

İkinci soruda öğrenciler üç farklı strateji kullanmıştır. Üçüncü soruyu yanıtlayan 33’ü üstün yetenekli 74 öğrenci, sorunun çözümü için toplam 86 strateji üretmiştir. Bu soruya yanıt veren toplam 12 öğrenci sorunun çözümü sırasında birden fazla strateji kullanmıştır. Ü33 kodlu öğrenci büyük sayıların verilen şekildeki orta bölümlerde yer alması gerektiğini, küçük 
sayılarında bunların etrafındaki en olanaklı yerlere yerleştirilmesi gerektiğini belirtmiştir (Tablo 5). Öğrencinin bu ifadesinden mantıksal akıl yürütme stratejisini kullandığ anlaşılmaktadır. Ayrıca öğrenci akıl yürütme stratejisiyle elde ettiği bu fikir yardımıyla sayılar arasında ilişki kurarak verilen sayıları en olanaklı yerlere yerleştirmiştir. Ü42 kodlu öğrenci ise test etme tahmin etme stratejisini kullanarak satır ve sütunların toplamlarının 31 olduğunu elde ederek soruyu çözmüştür.

Öğrenciler sorunun çözümünde her ne kadar üç farklı strateji kullanmış olsa da Tablo 2'de görüldüğü gibi bu sorunun çözümünde diğer öğrencilerin üstün yeteneklilere göre daha fazla strateji ürettikleri ve bu sorunun çözümü için birden fazla strateji kullanan öğrencilerin sayısının diğerlerinin lehine olduğu görülmektedir. Ayrıca, diğer öğrenciler bu soruyu doğru yanıtlamada üstün yeteneklilere göre hem sayısal hem de oransal (üstün yetenekli öğrenciler: $\% 0,24$, diğer öğrenciler: \%0,34 ) olarak daha başarılıdır.

Tablo 6: Üçüncü sorunun analizleri ve örnek öğrenci yanıtları

Soru 3: Bir kızın erkek kardeşlerinin ve kız kardeşlerinin sayısı birbirine eşittir. Fakat her erkeğin kız kardeşlerinin sayısı, diğer erkek kardeşlerinin sayısının 2 katıdır. Bu ailede kaç kız, kaç erkek kardeş vardır?

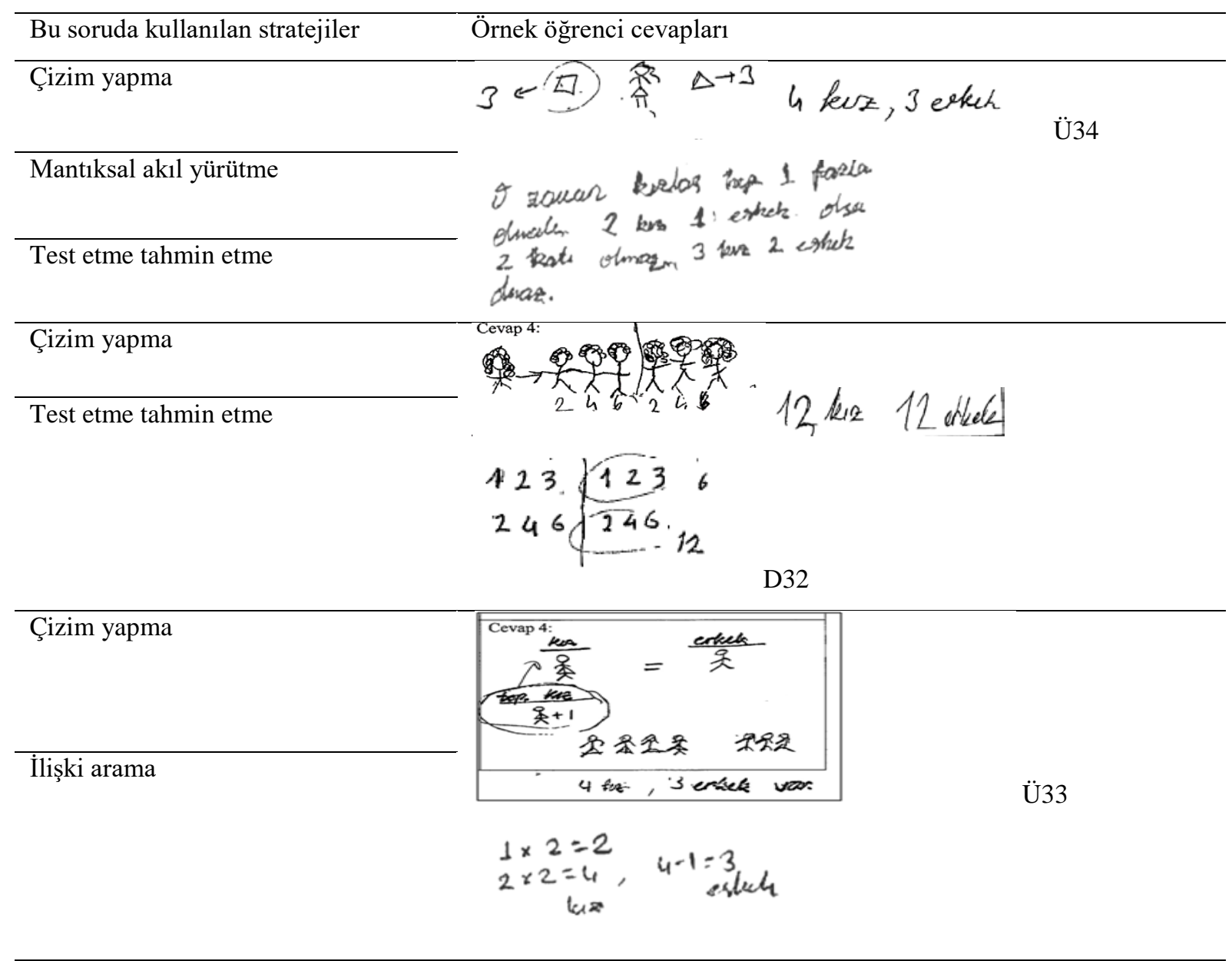


Üçüncü soruda öğrenciler dört farklı strateji kullanmıştır. Bu soruya 52 öğrenci çözüm üretmiş ve öğrencilerin çözümlerinde toplam 66 strateji kullanılmıştır. Ayrıca bu soruda üstün yetenekli öğrenciler diğerlerine göre mantıksal akıl yürütme stratejisini (5 adet) fazladan kullanmıştır. Bununla beraber üstün yetenekli öğrencilerin bu soruyu diğerlerine göre daha fazla doğru yanıtladıkları tespit edilmiştir.

Her iki gruptaki öğrencilerin kullandıkları stratejiler içinde en fazla çizim yapma stratejisinin kullanıldığı belirlenmiştir (üstün yetenekliler 22 adet, diğerleri 17 adet). Bu durum öğrencilerin veriler arasındaki ilişkileri belirlemek için görsellerden yararlandıklarını ve yapılan şemalarla sorudaki verileri özetlediklerini göstermektedir. Tablo 6’da bu duruma örnek olarak Ü33 kodlu öğrencinin çizim yapma ve ilişki arama stratejilerini kullanarak soruda verilenleri özetlediği ve çözüm yaptığı görülmektedir. Öğrenci kız ve erkek bireyleri sembollerle ifade etmiştir. D32 kodlu öğrenci test etme tahmin etme ve çizim yapma stratejilerini kullanmıştır. Öğrencinin ilk olarak 1-2-3 sayıları ile ailedeki bireyleri eşleştirdiği ardından 2-4-6 sayılarını kullanarak eşleştirme yaptığı görülmektedir. Bu durumda öğrencinin test etme tahmin etme stratejisini kullandığı anlaşılmaktadır. Böylece 12 kız, 12 erkek çözümüne ulaşmıştır. Ü34 kodlu öğrenci verdiği cevapta "o zaman klzlar hep 1 fazla olmalı", yanıtıyla mantıksal akıl yürütme stratejisini kullanmıştır. Ardından sırasıyla 2 kız, 1 erkek olma durumundan başlayarak test etme tahmin etme stratejisini uygulamış ve sonuca ulaşmıştır. Ayrıca öğrenci kız ve erkek kardeşleri şekil kullanarak sembollerle ifade etmiş, ardından kız ve erkeklerin sayılarını bu eşleştirmeler yardımıyla elde etmiştir. 
Tablo 7: Dördüncü sorunun analizleri ve örnek öğrenci yanıtları

Soru 4: Bir çemberin üstünde sıralanan çocuklardan beşincisi ile on dokuzuncusu tam karşı karşlya denk gelmiştir. Bu çemberde toplam kaç çocuk siralanmıştır?

Bu soruda kullanılan Örnek öğrenci cevapları
stratejiler

İlişki arama

D39

Farklı bakış açısı ile

düşünme

D37

Verileri organize etme

Dördüncü soruda öğrenciler beş farklı strateji kullanmıştır. Soruya 48'i üstün yetenekli olan 86 öğrenci yanıt vermiş ve toplam 122 strateji kullanılmıştır. Öğrencilerin en fazla strateji çeşitliliğini bu soruda kullandıkları görülmektedir. Ayrıca, her iki gruptaki öğrencilerin en fazla bu soruda tek çözümde birden fazla strateji kullandıkları da ortaya çıkan durumlardan biridir (üstün yetenekliler 22 adet, diğerleri 14 adet). Öğrencilerin bu soruyu çözerken tümevarımsal düşünme yeteneklerini kullandıkları üstün yetenekli öğrencilerin diğerlerine göre daha fazla yanıt vererek daha fazla strateji geliştirdikleri tespit edilmiştir. Bu sorunun çözümü için beklenen stratejilerden (Tablo 1) öğrenciler mantıksal akıl yürütme stratejisini hiç kullanmamıştır.

Tablo 7'de yer alan D39 kodlu öğrencinin ilişki arama stratejisini kullandığı görülmektedir. Öğrenci 1'den başlayarak doğal sayıları sıralamış ve soruda verilen 5 ile 19. kişileri eşleştirerek çözümünü gerçekleştirmiştir. D37 kodlu öğrencinin farklı bakış açısı ile 
düşünme stratejisini kullanmıştır. Öğrenci çözümünde 5 ile 19. kişilerin karşı karşıya geldiği bilgisini kullanarak 19. kişiden sonraki kişilerin eşleştiği kişilerin numaralarını tespit etmiş ve nihayetinde 23. kişi ile 1. kişinin karşı karşıya geldiğini elde etmiştir. Fakat bu grupta 24 kişinin olması gerektiğini belirtememiştir. Verileri organize etme ve çizim yapma stratejilerini kullanan Ü4 kodlu öğrenci bir çember çizerek kişileri çizgilerle ifade etmiş ve bu çemberde karşı karşıya gelen 5 ile 19. kişileri eşleştirerek çözüm yapmıştır. Benzer olarak Ü34 kodlu öğrenci de sorudaki verileri kullanarak şekil çizmiş, 19 ile 5. kişiler arasındaki kişi sayısını kullanmış ve tahmin etme stratejisiyle çözüme ulaşmıştır. Ü52 kodlu öğrenci ise test etme tahmin etme ve çizim yapma stratejilerini kullanmıştır. Öğrenci her ne kadar şekil kullanarak verilenleri özetlese de test etme tahmin etme stratejisini etkin olarak kullanmıştır. Bu durum sorunun çözümünde kullandığı ifadelerden (“arada 13 kişi olmalı” gibi) anlaşılmaktadır.

Tablo 8: Beşinci sorunun analizleri ve örnek öğrenci yanıtları

\begin{tabular}{l}
\hline Soru 5: Hiçbir rakamı sıfır olmayan öyle iki doğal sayı bulunuz ki, çarpımları 1 milyon olsun? \\
\hline Bu soruda kullanılan $\quad$ Örnek öğrenci cevapları \\
stratejiler
\end{tabular}

Geriye doğru çalışma

Ü32

\begin{tabular}{|c|c|c|c|c|c|}
\hline İlişki arama & $\frac{56^{4}}{30} \frac{x^{\frac{2}{9}}}{10} \frac{y^{\frac{5}{4}}}{20}-\frac{y^{5}}{20} \frac{\gamma^{8}}{40}$ & 3 & & 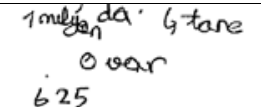 & \\
\hline Test etme tahmin etme & $\frac{3+18 \leq 1}{.}$ & $\begin{array}{r}25 \\
\times \quad 4 \\
100\end{array}$ & $\begin{array}{r}125 \\
\times \quad 16 \\
2000\end{array}$ & $\begin{array}{r}625 \\
\times \quad 16 \\
10000\end{array}$ & Ü45 \\
\hline
\end{tabular}

Beşinci soruda öğrenciler üç farklı strateji kullanmıştır. Hem verilen toplam yanıt sayısı (30 adet) hem de kullanılan toplam strateji sayısı (33 adet) bakımından en düşük veri bu soruda ortaya çıkmıştır. Öğrenciler bu soruda en fazla geriye doğru çalışma stratejisini (16 adet) etkin olarak kullanmıştır. Bununla birlikte her iki gruptaki öğrencilerde çözümlerinde aynı stratejileri kullanmıştır. Öğrenciler, bu sorunun çözümü için beklenen stratejilerden (Tablo 1) mantıksal akıl yürütme ve daha basit benzer problemlerle düşünme stratejilerini hiç kullanmamıştır.

Tablo 8'de yer alan örnek öğrenci cevapları incelendiğinde Ü32 kodlu öğrencinin geriye doğru çalışma stratejisini kullandığı görülmektedir. Öğrencinin cevabında 1 milyon sayısını 
sürekli 2’ye böldüğü, böylece sayının içindeki 2 ve 5 çarpanlarını birbirinden tamamen ayırdığı görülmektedir. İlişki arama stratejisini kullanan Ü45 kodlu öğrenci 4, 5, 6 ve 16 ile çarpıldıklarında çarpımında sıfır olan sayıların bir kısmını elde etmiştir. Bu yönüyle bakıldığında öğrencinin test etme tahmin etme stratejisini de uyguladığı söylenebilir. Ayrıca öğrencinin 1 milyonda 4 tane sıfır var şeklindeki yorumundan sayının içindeki 10'un katlarının elde edilmesine yönelik ilişki aradığı bir strateji geliştirdiği anlaşılmaktadır.

Tablo 9: Altıncı sorunun analizleri ve örnek öğrenci yanıtları

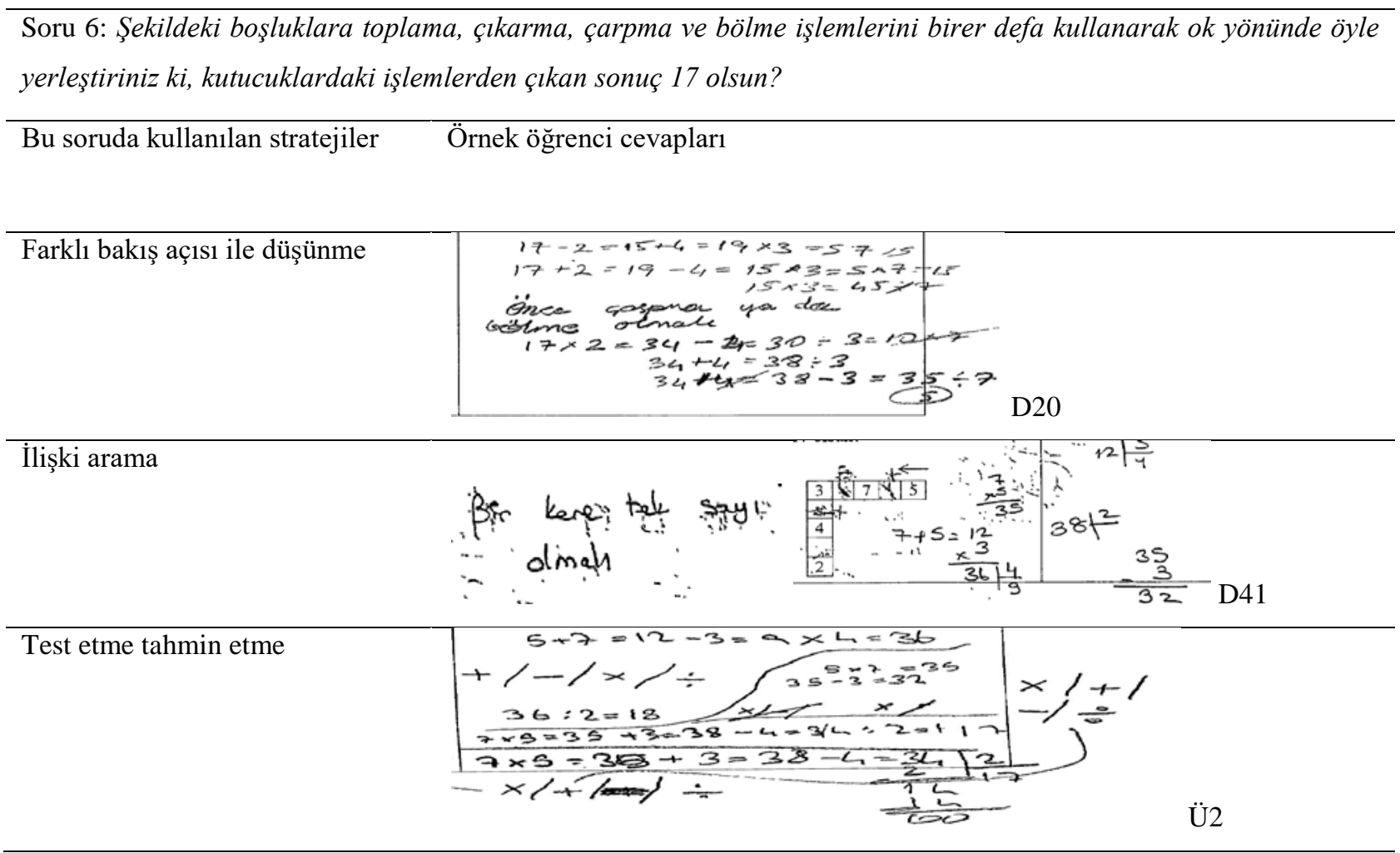

Altıncı soruda öğrenciler üç farklı strateji kullanmıştır. Soruya yanıt veren 34'ü üstün yetenekli olan 61 öğrenci toplam 66 strateji kullanmıştır. Bu soruda diğer öğrencilerin üstün yetenekli öğrencilerden farklı olarak farklı bakış açısı ile düşünme stratejisini fazladan kullandıkları görülmüştür. Tablo 2 incelendiğinde bu soruda her ne kadar diğer öğrenciler strateji çeşitliliği bakımdan farklılık yaratmış olsa da üstün yetenekli öğrencilerin diğerlerine göre daha fazla strateji geliştirerek çözüm yaptıkları ve doğru yanıtlarının diğer öğrencilerden daha fazla olduğu görülmektedir. Ayrıca, bu sorunun çözümünde üstün yetenekli öğrenciler (23 adet) diğerlerine (4 adet) göre soruyu doğru yanıtlama bakımından da oldukça başarılı olmuştur. Bu sorunun çözümü için beklenen stratejilerden (Tablo 1) öğrenciler mantıksal akıl yürütme, 
geriye doğru çalışma, tüm olası durumları düşünme ve verileri organize etme stratejilerini hiç kullanmamıştır.

Üstün yetenekli öğrenciler bu sorunun çözümünde en fazla test etme tahmin etme stratejisini (21 adet) kullanmıştır. Ü2 kodlu öğrencinin bu soruya verdiği cevap incelendiğinde bu duruma örnek olarak test etme tahmin etme stratejisini kullandığı görülmektedir. Öğrenci işlemlerin sıralarını değiştirerek denemelerde bulunmuş ve nihayetinde çözüm için gerekli işlem sıralamasını elde etmiştir. Farklı bakış açısı ile düşünme stratejisini kullanan D20 kodlu öğrenci önce istenilen sonucu (17 cevabını) kullanarak test etme tahmin etme stratejisi ile işlemlerine başlamış, ardından “önce bölme ya da çarpma olmalı” diye belirterek çözüm yapmaya devam etmiş böylece ilk kullanılan sayıya ulaşmayı başarmıştır. "Bir kere tek sayı olmalı" diyerek işlemlerine başlayan D41 kodlu öğrencinin sorunun çözümünde test etme tahmin etme ve ilişki arama stratejilerini birlikte kullandığı söylenebilir. Bunun yanı sıra işlemleri kutucuklara yerleştirirken test etme tahmin etme stratejisinden de faydalandığ anlaşılmaktadır.

$\mathrm{Bu}$ çalışmada öğrencilerin matematik sorularına geliştirdikleri strateji çeşitliliğine odaklanıldığından, soruların doğru ya da yanlış cevaplanmalarıyla ilgili bilgilere kısaca değinilmiştir. Bununla beraber yapılan çalışmada üstün yetenekli öğrencilerin (68 adet) verdikleri cevaplarda diğerlerine (32 adet) göre daha fazla sayıda doğru yanıt verdikleri gözlemlenmiştir (Tablo 2). Bunun yanı sıra diğer öğrencilerin verdikleri cevaplardaki yanlış sayıları da üstün yetenekli öğrencilere göre daha fazladır. Her ne kadar strateji kullanımları bakımından iki grup arasında ciddi farklılıklar görülmese de üstün yetenekli öğrencilerin soruları doğru yanıtlama açısından diğerlerinden daha başarılı oldukları söylenebilir.Üstün yetenekli öğrenciler 1. ve 3. sorularda diğer öğrencilerden farklı stratejiler kullanırken diğer öğrenciler 6. soruda üstün yetenekli öğrencilerden farklı strateji kullanmıştır. Ayrıca öğrencilerin tamamı çözümlerinde uç durumları düşünme, tüm olası durumları düşünme ve daha basit benzer problemlerle düşünme stratejilerini hiç kullanmamıştır. Elde edilen sonuçlara göre üstün yetenekli öğrencilerin diğer öğrencilere göre sorulara geliştirdikleri strateji çeşitliliği ve aynı soruda birden fazla strateji yardımıyla çözüm aramaları bakımından farklılaştıkları görülmektedir. 


\section{Tartışma}

Araştırmada ilkokul 4. sınıf üstün yetenekli öğrenciler ile diğer öğrencilerin kendilerine sorulan matematik sorularında kullandıkları stratejiler ile bu iki grubun kullandıkları strateji farklılıkları incelenmiştir. Yapılan çalışma sonucunda her iki gruptaki öğrencilerin de kendilerine sorulan açık uçlu sorularda kendilerine özgü bir strateji geliştirebildikleri ve bu stratejileri kullanabildikleri gözlenmiştir. Bu bakımdan dördüncü ve beşinci sınıf öğrencilerinin rutin olmayan problemlerde geliştirdikleri stratejilerin araştırıldığı Verschaffel, De Corte ve diğerleri (1999) ile Yazgan'ın (2007) çalışmalarında elde ettikleri öğrencilerin problem çözme stratejilerini kavrayabilmeleri, uygun stratejileri seçebilmeleri ve kendilerine özgü stratejiler geliştirebilmeleri sonuçları bakımından benzerlik taşımaktadır.

$\mathrm{Bu}$ çalışmada öğrencilerin problemleri doğru ya da yanlış çözme durumları incelendiğinde üstün yetenekli öğrencilerin lehine sonuçlar elde edilmiştir. Nitekim Renzulli (1978) aynı yaştaki üstün yetenekli olan ve olmayan öğrencilerin problem çözme durumlarını inceledikleri çalışmalarında üstün yetenekli öğrencilerin diğerlerine göre problem çözmede daha iyi olduklarını ifade etmektedir. Bunun yanı sıra Tablo 2'ye bakıldığında üstün yetenekli öğrencilerin kısmen zor olan birinci, ikinci ve beşinci sorularda diğerlerinden farklılaştıkları ve bu sorularda diğerlerine göre daha fazla strateji ürettikleri görülmektedir. Bu durum Tertemiz, Doğan ve Karakaş'ın (2017) yaptıkları çalışmalarında üstün yetenekli öğrencilerin rutin olmayan problemleri çözmede hata sayılarının çok az olduğunu ve en az iki farklı problem çözme stratejisini kullanabildikleri sonucuyla benzerlik taşımaktadır. Montague, Bos ve Doucette (1991) ise yaptıkları çalışmada üstün yetenekli öğrencilerin problemi görür görmez çözüm getirdiklerini ve stratejiler hakkında daha çok bilgiye sahip olduklarını belirtmiştir. $\mathrm{Bu}$ çalışmada ise bunun aksine, üstün yetenekli öğrencilerle diğerlerinin sorulara verdikleri yanıt sayıları ile sorularda kullandıkları strateji sayılarının birbirine yakın olduğu göze çarpmaktadır. Uygulamadan elde edilen sonuçlara göre; öğrencilere soruları çözmeleri için verilen 1 ders saati süresinde her iki öğrenci grubunun bir kısmının tüm soruların çözümünü tamamlayabildiği, bir kısmının ise bu süre zarfında tüm soruların çözümünü tamamlayamadığı görülmüştür. Elizabeth, Oaks ve Sanders (2002) yaptıkları çalışmalarında öğrencilere sınırlı zaman verilmesinin, öğrencilerin problem çözme stratejilerini kullanmaktan kaçınmalarının nedenlerinden biri olduğu sonucunu elde etmiştir. Bu bakımdan üstün yetenekli öğrencilerle diğerlerinin birbirlerine yakın sayıda strateji kullanmaları ve iki grup arasında kullanılan strateji 
çeşitliliğinin çok farklı çıkmaması, öğrencilerin soruları çözmeleri için kendilerine verilen süreden kaynaklanmış olabilir.

Matematiksel akıl yürütme (muhakeme etme ve ilişki kurma), öğrencinin eleştirel düşünme ve mantıksal sonuçlar geliştirmelerini de beraberinde getirmektedir. Yapılan çalışmada öğrencilerin problem çözümlerinde test etme tahmin etme stratejisini kendilerine sorulan tüm sorularda sıklıkla kullandıkları görülmüştür. Bu durum, öğrencilerin problem çözümlerine eleştirel ve sezgisel atılımlar geliştirerek matematiksel akıl yürütme becerilerini kullanmaya çalışmalarından kaynaklanabilir. Ayrıca problem çözümlerinde sistematik olarak verileri ilişkilendirmek ve akıl yürüterek farklı denemeler yapmak faydalı olabilir. Öğrencilerin bu gibi süreçleri farkında olmadan test etme tahmin etme stratejisi yardımıyla kullanmaya çalıştıkları söylenebilir. Nitekim Akkan, Baki ve Çakıroğlu (2012) ortaokul öğrencilerinin aritmetikten cebire geçiş süreçlerini problem çözme bağlamında inceledikleri çalışmalarında, öğrencilerin problem çözerken test etme tahmin etme stratejisini sıklıkla kullanarak problemlerdeki bilinmeyenleri elde etmeye çalıştıklarını söylemektedir. Düzakın (2004) ise yaptığı çalışmasında test etme tahmin etme stratejisini kullanan öğrencilerin birbirleriyle bağlantısız görünen fikirler arasında ilişkileri arayarak problem çözme aşamasında soyut şeyleri somutlaştırarak ve sentezleyerek daha genel bir düşünme yapısını gösterdiklerini belirtmektedir.

Araştırmada üstün yetenekli öğrencilerin geriye doğru çalışma ve mantıksal akıl yürütme stratejilerini diğerlerine göre daha fazla kullandıkları görülmüştür. Ayrıca genel olarak her iki gruptaki öğrenciler problem çözümlerinde ilişki arama, test etme tahmin etme ve çizim yapma stratejilerini etkin biçimde kullanmışlardır. Bu durum Altun ve Memnun'un (2008) yaptıkları çalışmada mantıksal akıl yürütme, geriye doğru çalışma, diyagram çizme, tablo yapma ve problemi basitleştirme stratejilerinin problem çözmede başarılı ya da başarısız ayırımını yapmada güçlü etkiye sahip oldukları sonucuyla örtüşmektedir. Tablo 2'de görüldüğü gibi her iki gruptaki öğrenciler geriye doğru çalışma, farklı bakış açısı ile düşünme ve verileri organize etme stratejilerini az kullanmıştır. Öğrencilerin alışılmadık bir problemle karşılaştıklarında bu stratejileri kullandıkları bilinmektedir (Altun ve Arslan, 2006). Okullarda ise öğrenciler çoğunlukla bilindik problemlerle karşılaşırlar ve bir an önce çözüme ulaşacakları hamlelerle problemleri çözme eğilimine girerler. Bunun yanı sıra öğrencilerin problem çözme stratejilerine yönelik bir eğitim almasalar da genel olarak stratejileri etkin biçimde kullanabildikleri sonucu ortaya çıkmıştır. Nitekim Yazgan ve Bintaş (2005) yaptıkları 
çalışmalarında, öğrencilerin problem çözme stratejilerine yönelik eğitim almasalar da, bazı stratejilerin informal olarak kendiliğinden gelişebildiği sonucuna varmışlardır.

Tablo 2 incelendiğinde dikkat çeken bir diğer durum, üstün yeteneklilere göre diğer öğrencilerin altıncı soruda farklı bakış açısı ile düşünme stratejisini fazladan kullanmış olmalarıdır. Altıncı soruda her ne kadar diğer gruptaki öğrenciler farklı bakış açısı ile düşünme stratejisini üstün yetenekli öğrencilere göre fazladan kullansalar da, üstün yetenekli öğrencilerin bu sorunun çözümünde daha pratik çözüm yollarını tercih ederek, verdikleri doğru cevap sayılarının diğerlerine göre çok fazla olduğu belirlenmiştir. Bunun yanı sıra birinci soruyu genel olarak her iki gruptaki öğrenciler doğru çözemeseler de, bu sorunun çözümü için oldukça fazla sayıda strateji denemişlerdir. Bu soru; soruyu doğru çözme, strateji kullanma ve yanıt geliştirme, birden fazla stratejiyi aynı soruda kullanma ve üretilen stratejilerdeki farkl1lıklar bakımlarından incelendiğinde üstün yetenekli öğrencilerin diğerlerine göre daha başarılı oldukları görülmektedir. Miller (1990) yaptı̆ğ araştırmada matematikte üstün yetenekli öğrencilerin problem ifadesini değiştirmede, materyalleri organize etmede ve problemi farklı yollarda çözmede başarılı olduklarını belirtmektedir. Birinci soruda oluşan bu durumu Miller'in yaptığı çalışmanın sonuçları desteklemektedir.

Özetle, problem çözümlerinde kullanılan stratejiler ve sorulara ürettikleri cevaplar bakımından üstün yetenekli olan ve olmayan öğrenciler arasında ciddi bir farklılık görülmese de üstün yetenekli öğrencilerin diğerlerine göre bir problemin doğru ya da yanlış cevaplanması, problem çözümlerinde kullanılan stratejiler ve aynı sorunun çözümü için birden fazla stratejiyi geliştirip kullanabilmeleri bakımından daha başarılı oldukları belirlenmiştir. Ayrıca her iki grup birlikte düşünüldügünde test etme tahmin etme stratejisini etkin biçimde kullandıkları ve iki grubun da uç durumları düşünme, tüm olası durumları düşünme ve daha basit benzer problemlerle çözme stratejilerini hiç kullanmadıkları ortaya çıkmıştır.

\section{Sonuç ve Öneriler}

Bu çalışmada öğrenciler genel olarak her sorunun çözümü için strateji geliştirebilmiş, bunun yanı sıra üstün yetenekli öğrenciler diğerlerine göre daha fazla strateji çeşitliliği kullanmıştır. Üstün yetenekli öğrencilerin diğerlerine göre problem durumu hakkında sahip oldukları bilgi ve düşünceleri çeşitli stratejiler kullanarak ilişkilendirebildikleri görülmüştür. Nitekim yapılan araştırmalarda üstün yetenekli öğrencilerin doğaları gereği, sorulara uygun modeller oluşturup ürettikleri bu modelleri problem çözümlerinde kullanmada daha başarılı 
oldukları tespit edilmiştir (Renzulli, 1978). Üstün yetenekli öğrencilerin birinci ve üçüncü sorularda daha fazla strateji kullanmaları bu duruma örnek olarak verilebilir. Ayrıca üstün yetenekli öğrenciler aynı sorunun çözümünde birden fazla stratejiyi kullanabilmekte (Tablo 3) ve doğru çözümlere ulaşabilmektedir. Öğrencilerin farklı stratejileri kullanabilmeleri bilişsel düzeyleri ile yakından ilişkili olup (Yıldız, Baltacı ve Kuzu, 2018) üstün yetenekli öğrencilerin problem çözme becerisine yönelik bilişsel düzeylerinin yüksek olduğu belirtilmektedir (Tüysüz, 2013). Bu nedenle üstün yetenekli öğrencilerin yaratıcılıklarının ve bilişsel yeteneklerinin geliştirilmesi için karmaşık ve kendilerini zorlayan problemlerle uğraştırılmaları (Diezmann ve Watters, 2002) gerekmektedir. Bu tür kendilerini zorlayıcı problemlerle uğraşmaları, öğrencilerin matematiğe verdikleri değeri ve motivasyonlarını arttırıcı bir etken olabilir (Lupkowski-Shoplik ve Assouline, 1994). Dolayısıyla üstün yetenekli öğrencilere ilgilerini çekecek ve kendilerini geliştirebilecekleri firsat ve ortamlar sağlanarak öğrencilerin matematiğe ve uğraştıkları görevlere ilgilerinin geliştirilmesi faydalı olabilir.

Yürütülen araştırma sonuçlarına göre hem üstün yetenekli hem de diğer öğrenciler informal olarak strateji geliştirebilmekte ve bu stratejileri özgün olarak problem çözümlerinde kullanabilmektedir. Araştırmaya katılan diğer dördüncü sınıf öğrencilerinin üstün yetenekli olduğu tespit edilmiş öğrencilere yakın sayıda strateji geliştirebildikleri, problem çözümlerinde özgün yaklaşımlar sergileyebildikleri görülmüştür. Bu durum, Kılıç (2015) ve Bilgili'nin (2000) çalışmalarında da belirttikleri gibi, üstün yetenekli öğrencilere yönelik eğitim konusunda düzenli bir politika oluşturulamamış olmasından kaynaklanıyor olabilir. Ülkemizde Bilim Sanat Eğitim Merkezi’ne (BİLSEM) öğrenci seçimi için dördüncü sınıf düzeyinde genel bir sınav yapılmaktadır (MEB, 2016). İl Millî Eğitim Müdürlükleri tarafından bu sınava yönelik okullara bilgilendirme yapılmakta, fakat il genelinde her okula ulaşılamamaktadır. Keskin, Samancı ve Aydın'ın (2013) çalışmalarında da belirttiği üzere BİLSEM'ler tarafından yürütülen tanılama sınavları kamuoyuna ve öğrenci velilerine yeterince duyurulamamaktadır. $\mathrm{Bu}$ da üstün yetenekli öğrencilerin tanılamasına yönelik yapılacak çalışmaların yetersiz kalmasına, bu potansiyeldeki öğrencilerin belirlenememesine neden olmaktadır. İl Millî Eğitim Müdürlüklerinin konu ile ilgili çalışmalarında daha sistematik bir yap1 oluşturması, bu özellikteki öğrencilerin tespit edilmesi ve potansiyellerinin geliştirilebilmesi açısından önem arz etmektedir. Ayrıca üstün yetenekli öğrencilere eğitim veren öğretmenlerin bu konuda eğitim almış olmaları ve uygulanan eğitim programlarının öğrencilerin özelliklerine yönelik hazırlanmış olması gerekmektedir. Böylece Millî Eğitim Bakanlığı, ilkokul programında problem çözme stratejilerinin öğretimine yer vermeli ve öğretmenlere problem çözme 
stratejilerinin öğretimi için hizmet içi eğitim kursları düzenlemelidir. Buna ek olarak, Millî Eğitim Bakanlığı ilkokul matematik ders kitaplarının içeriğinde farklı problem çözme stratejilerinin kullanılmasını gerektiren problemlere yer vermeli ve öğretmenlere matematik derslerinde kullanabilecekleri kaynak materyaller hazırlamalıdır.

\section{Makalenin Bilimdeki Konumu}

Matematik ve Fen Bilimleri Eğitimi/Matematik Eğitimi

\section{Makalenin Bilimdeki Özgünlüğü}

Literatürde hem üstün yeteneklilerle hem de problem çözme stratejileri ile ilgili farklı bakış açılarının kullanıldığı çalışmalar yer almaktadır. Ancak ilkokul dönemindeki üstün yetenekli öğrencilerin problem çözme becerileri ve kullandıkları problem çözme stratejileri merak konusudur. $\mathrm{Bu}$ nedenle bu çalışmada ilkokulda öğrenim gören üstün yetenekli öğrencilerin üst düzey düşünme becerilerini kullanma durumları diğer akranlarıyla karşılaştırılarak incelenmiştir.

\section{Kaynakça}

Akgün, Ö., Büyüköztürk, Ş., Çakmak, E., Demirel, F., \& Karadeniz, Ş. (2010). Bilimsel araştırma yöntemleri.

Akkan, Y., Baki, A., \& Çakıroğlu, Ü. (2012). 5-8. Sınıf Öğrencilerinin Aritmetikten Cebire Geçiş Süreçlerinin Problem Çözme Bağlamında İncelenmesi. Hacettepe Üniversitesi Ĕ̈itim Fakültesi Dergisi, 43(43).

Altun, M. (2002). İlköğretim ikinci kademede matematik öğretimi. Bursa: Alfa Yayıncılık.

Altun, M. (2010). İlköğretim İkinci Kademede (6, 7 ve 8. Sınıflarda) Matematik Öğretimi. Bursa: Aktüel Alfa Yayınevi.

Altun, M. \& Arslan, Ç. (2006). İlköğretim öğrencilerinin problem çözme stratejilerini öğrenmeleri üzerine bir çalışma. Uludağ Üniversitesi Ĕ̌itim Fakültesi Dergisi, 19(1).

Altun, M. and Memnun, D. S.,2008. Mathematics teacher trainees' skills and opinions on solving non-routine mathematical problems, Journal of Theory and Practice in Education, $4(2), 213-238$. 
Artut, P. D. \& Aslan, E. (2014). İlköğretim Matematik Dersi Öğretim Programında Yer Alan Tahmin Becerisinin Öğretmen Görüşleri Doğrultusunda Değerlendirilmesi. Çukurova Üniversitesi Sosyal Bilimler Enstitüsü Dergisi, 23(1), 239-250.

Baykul, Y. \& Aşkar, P. (1987). Problem ve problem çözme, Matematik öğretimi. Açıköğretim Fakültesi Yayınları, (94).

Bilgili, A. E. (2000). Üstün yetenekli çocukların eğitimi sorunu-sosyal sorumluluk yaklaşımı.

Bingham, A. (1998). Çocuklarda problem çözme yeteneklerinin geliştirilmesi [Improving children’s facility in problem-solving]. (Translator: A. Ferhan Oğuzhan). İstanbul: Milli Eğitim Basımevi

Charles, R. \& Lester, F. (1982). Teaching problem solving: What, why \& how. Palo Alto, CA: Dale Seymour Publications.

Coutinho, S.,Weimer-Hastings, K., Skowronski, J. J. \& Britt, M. A. (2005). Metacognition, Need for Cognition and Use of Explanations During On Going Learning and Problem Solving. Learning and Individual Differences, 15, 321-337.

Diezmann, C. M. \& Watters, J. J. (2002). Summing up the education of mathematically gifted students.

Düzakın, S., 2004. Lise öğrencilerinin problem çözme becerilerinin bazı değişkenler açısından incelenmesi, Yüksek lisans tezi, Gazi Üniversitesi, Ankara.

Elizabeth, M., Oaks, T. and Sanders, T., 2002. Improving students achievement through inclusion of problem solving in the math curriculum. Master of Arts Action Research Project. Saint Xavier University and Skylight Professional Development Field-Based Master’s Program.

Gündüz, N. ve Bulut, A. S. (2017). Öğretmen adaylarının geometrik cisimler konusundaki bilgi düzeyleri, problem çözme düzeyleri ve tutumlarının incelenmesi. Inönü Üniversitesi Eğitim Fakültesi Dergisi, 18(2), 01-15.

Güzel, A. (2004). Marmara Üniversitesi öğrencilerinin öğrenme stilleri ile problem çözme becerileri arasındaki ilişkinin incelenmesi. Yayınlanmamış Yüksek Lisans Tezi, İstanbul: Marmara Üniversitesi, Sosyal Bilimler Enstitüsü. 
Hancock, D. R. \& Algozzine, B. (2016). Doing case study research: A practical guide for beginning researchers. Teachers College Press.

Hatfield, M. M., Edwards, N. T. \& Bitter, G. G. (1997). Mathematics methods for elementary and middle school teachers. Boston: Allyn-Bacon.

Heppner, P. P. \& Krauskopf, C. J. (1987). An information-processing approach to personal problem solving. The Counseling Psychologist, 15(3), 371-447.

Huberman, A. M. \& Miles, M. B. (1994). Data management and analysis methods.

Kennedy, L. And Tipps, S. (1991). Guiding children'slearning of mathematics. California: Wadsworth Publishing Company.

Keskin, M. Ö., Samanc1, N. K. \& Aydın, S. (2013). Science and Art Centers: Current Status, Problems, and Solution Proposals. Journal of Gifted Education Research, 1(2), 78-96.

Kılıç, V. C. (2015). Türkiye'de Üstün Ve Özel Yetenekli Çocuklara Yönelik Bir Eğitim Politikası Oluşturulamaması Sorunu Üzerine Bir Değerlendirme. 21. Yüzyılda Eğitim ve Toplum Eğitim Bilimleri ve Sosyal Araştırmalar Dergisi, 4(12).

Krutetskii, V. A. (1976). The Psychology of Mathematical Abilities in School Children, University of Chicago Press, Chicago.

Lester, F. K. (1994). Using about mathematical problem solving researchs: 1970-1994. Journal for Research in Mathematics Education, 25(6), 660-675.

Lupkowski-Shoplik, A. E. \& Assouline, S. G. (1994). Evidence of extreme mathematical precocity: Case studies of talented youths. Roeper Review, 16(3), 144-151.

Mesleki Eğitim ve Öğretim Sisteminin Güçlendirilmesi Projesi (MEGEP), (2009). Üstün Zeka ve Özel Yetenekli Çocuklar, Çocuk Gelişimi ve Eğitimi, Ankara.

Miller, R. C. (1990). Discovering Mathematical Talent, ERIC EC Digest E482, ED 321487.

Milli Eğitim Bakanlığı [MEB], (2009). İlköğretim Matematik Dersi, 6-8. Sınıflar Öğretim Program1. Ankara. MEB.

Milli Eğitim Bakanlığı [MEB], (2015). İlkokul matematik dersi (1, 2, 3 ve 4. sınıflar) sınıflar öğretim programı ve kılavuzu. Ankara: Talim ve Terbiye Kurulu Başkanlığı.

Montague, M., Bos, C. S. and Doucette, M., 1991. Affective, cognitive, and metacognitive attributes of eighth-grade mathematical problem solvers. Learning Disabilities Research \& Practice, 6 (3), 145-151. 
Morgan, C.T. (1981). Psikolojiye Giriş Ders Kitabı. (Çeviren: ARICI, H. ve dĭ̆.). Ankara: Hacettepe Üniversitesi Psikoloji Bölümü Yayınları, No:1.

National Council of Teachers of Mathematics (1989) .Curriculum and evaluation standards for school mathematics. Reston, Virginia.

National Council of Teachers of Mathematics, (2000). Principles and standards for school mathematics. Reston, VA 20191-9988.

Council of Chief State School Officers (CCSSO). (2010). Common Core State Standards.

Özbay, Y. (2013). Üstün yetenekli çocuklar ve aileleri. Ankara: Hangar Marka İletişimi ve Reklam Hizmetleri.

Patton, M. Q. (1987). How to use qualitative methods in evaluation (No. 4). Sage.

Polya, G. (1997). Nasıl çözmeli? (çev.) Feryal Halatçı, İstanbul: Sistem Yayıncılık. (ss.168169).

Posamentier, A. S. and Krulik, S., 1998. Problem-solving strategies for efficient and elegant solutions. California, Corwin Press Inc.

Renzulli, J. S., 1978. What makes giftedness? Phi Delta Kappan, 60, 180- 184.

Renzulli, J.S. \& Reis, S.M. (1985). The schoolwide enrichment model: A comprehensive plan for educational excellence, Mansfield Center, CT: Creative Learning Press.

Schoenfeld, A. H. (1991). What's all the fuss about problem solving?.Zentrallblattfur Didaktik der Mathematik (ZDM), Vol23(1), 4-8.

Tertemiz, N. I., Doğan, A., \& Karakaş, H. (2017). A comparative study on problem solving strategies of gifted 4th grade students and their high-achieving counterparts. Uluslararast Ĕgitim Programları ve Öğretim Çalışmaları Dergisi, 7(13), 161-188.

Tüysüz, C. (2013). Üstün yetenekli öğrencilerin problem çözme becerisine yönelik üstbiliş düzeylerinin belirlenmesi. Mustafa Kemal Üniversitesi Sosyal Bilimler Enstitüsü Dergisi, 10(21), 157-166.

Van Garderen, D. \& Montague, M. (2003). Visual-spatial representation, mathematical problem solving and students of varying abilities. Learning Disabilities Research \& Practice, 18(4), 246-254.

Verschaffel, L., De Corte, E., Lasure, S.,Van Vaerenbergh, G., Bogaerts, H. \& Ratinckx, E. (1999). "Learning to Solve Mathematical Application Problems: A Design Experiment with Fifth Graders”, Mathematical Thinking \& Learning. 1(1), 195-229. 
Woo, S. E., Harms, P. D. \& Kuncel, N. R. (2007). Integrating Personality and Intelligence: Typical Intellectual Engagement and Need for Cognition. Personality and Individual Differences, 43, 1635-1639.

Yazgan, Y. \& Bintaş, J. (2005). İlköğretim dördüncü ve beşinci sınıf öğrencilerinin problem çözme stratejilerini kullanabilme düzeyleri: Bir öğretim deneyi. Hacettepe Üniversitesi Ĕ̌itim Fakültesi Dergisi, 28(28).

Yazgan, Y. (2007). Dördüncü ve beşinci sınıf öğrencilerinin rutin olmayan problem çözme stratejileriyle ilgili gözlemler. İlköğretim Online, 6(2).

Yıldırım, A. \& Şimşek, H. (2005). Sosyal bilimlerde nitel araştırma yöntemleri (5. Bask1). Ankara: Seçkin Yayıncılık.

Yildiz, A., Baltaci, S., \& Kuzu, O. (2018). The investigation of students'cognitive and metacognitive competencies according to different variables. European Journal of Education Studies, 4(10), 81-98.

Yin, R. (1994). Case study research: Design and methods . Beverly Hills.

http://orgm.meb.gov.tr/meb_iys_dosyalar/2015_08/27014859_bilsemynerge.pdf

(Erişim

Tarihi: 12.11.2016)

https://orgm.meb.gov.tr/meb_iys_dosyalar/2015_11/19105341_rencitanlamaklavuzu.pdf

(Erişim

Tarihi: 01.12.2016)

\section{Summary}

\section{Statement of Problem}

Nowadays, alternative methods and practices have started to attract attention in order to reveal and develop the talents of learners. Problem solving methods increase the importance of these applications. Improving students' problem solving skills will also be effective in achieving social development. The development of students' problem solving skills of the students enables them to develop strategies that are appropriate for different problems, while also facilitating their understanding of mathematical knowledge. Due to the importance of problem solving, it is discussed with details in school curriculums around the world. 
When the literature is examined, it is seen that there are many studies about gifted students and their problem solving skills. In these studies, it is stated that the gifted people have highly developed problem-solving skills and can solve problems using different strategies. Considering the need for thinking, the functionality of solving problems in real-world conditions and its relationship with intelligence, problem-solving strategies of gifted individuals constitute a curiosity factor.

\section{Method}

This study aims to examine fourth grade gifted and other primary school students' mathematical problem solving strategies. This qualitative research was carried out with 110 primary students (55 gifted and 55 other student) from three different cities. A test consisting of 6 open-ended questions was used as data collection tool and the obtained data were analysed by qualitative methods.

\section{Findings}

When Table 2 is examined, it can be seen that both the gifted students and other students had the same number of answers to the questions. And they used similar solutions for the problems. In the study, students' correct answer rate is low but they used various problem solving strategies. Although some students made mistakes while solving problems, they could produce strategies. According to the results, both the gifted and other students have developed more than one strategy to solve the same questions. Another result of the study is that the students in both groups have used the trial and error strategy in all questions. Conducting different experiments by reasoning and relate systematically problem solutions may be useful for students. It can be said that students are trying to use these processes without being aware of solving the problem. Furthermore, it is seen that gifted students prefer to use the strategies of working backwards and logical reasoning more than others.

Although the strategies used by both groups are similar, it can be said that gifted students are more successful than others in terms of answering the questions correctly. Moreover, gifted students used different strategies from other students in questions 1 and 3; and other students used different strategies than gifted students in question 6. According to the results, it is seen that gifted students differ in terms of the strategy variety and the search for solutions with the help of more than one strategy in the same question. 


\section{Discussion and Conclusion}

The results indicate that the numbers of answers given by gifted and other students were close to each other, and it has been determined that the number of strategies developed by the students and the diversity of strategies they produced were higher in favor of the gifted students. It has also been observed that gifted students gave more correct answers to the open-ended questions comparing to other students. Similarly, it was obvious that gifted students used more than one strategy to solve the same question in most of the cases. In addition to these, the students in both groups mostly used trial and error strategy. On the other hand, none of the groups used the strategies, thinking about extreme situations, thinking about all possible situations and solving with simpler similar problems.

As a result of the study, it was observed that some students in both groups were able to use unique strategies. In this study, when students' solutions are examined in terms of correct and incorrect, it has been seen that number of correct answers are higher in favor of gifted students. As a matter of fact, Renzulli (1978) reported that gifted students are better at problem solving than others at the same age group. Furthermore, Table 2 shows that gifted students differentiate themselves from others in the first and third questions, which are partially difficult, and they have produced more strategies than others at these questions.

In the study, it was seen that both group of the students frequently used the trial and error strategy in all the questions. This may be due to students' ability to use reasoning skills by developing critical and intuitive breakthroughs in mathematical problem solving. In the research, it was seen that gifted students used backward working and logical reasoning strategies more than others. Besides in general, both groups of students have effectively used the searching relationship, trial and error and drawing strategies in their solutions.

Although the answers of gifted and other students do not differ from each other, gifted students are more successful than other students in terms of correctness, strategy development and strategy amount per question. In addition to this, it has been detected that both groups used the trial and error and searching relationship strategies more effectively, and did not use the strategies: thinking about extreme situations, thinking about all possible situations and solving problems with similar problems. 